\title{
Indirect costs of rheumatoid arthritis
}

\author{
Filip Raciborski ${ }^{1}$, Anna Kłak², Brygida Kwiatkowska ${ }^{3}$
}

${ }^{1}$ Department of Gerontology and Public Health, National Institute of Geriatrics, Rheumatology and Rehabilitation, Warsaw, Poland ${ }^{2}$ Department of Prevention of Environmental Hazards and Allergology, Medical University of Warsaw, Poland

${ }^{3}$ Early Arthritis Clinic, Institute of Rheumatology, Warsaw, Poland

\begin{abstract}
It is estimated that in Poland about 400,000 persons in general suffer from inflammatory joint diseases, including rheumatoid arthritis (RA). Epidemiological surveys documenting the frequency and disturbance of musculoskeletal disorders in the Polish population are few in number. Most of the estimations are based on epidemiological data from other countries (prevalence of $0.5-1 \%$ ). According to the data of the National Health Fund in Poland 135,000-157,000 persons in total are treated because of rheumatoid arthritis per year [ICD10 (International Statistical Classification of Diseases and Related Health Problems): M05, M06]. In the case of this group of diseases indirect costs significantly outweigh the direct costs. Indirect costs increase together with activity level of the disease. The cost analysis of productivity loss of RA patients indicates that sickness absenteeism and informal care are the most burdensome. At the national level it amounts in total from 1.2 billion to 2.8 billion PLN per year, depending on the method of analysis. These costs could be significantly reduced through early diagnosis and introduction of effective treatment.
\end{abstract}

Key words: rheumatoid arthritis, indirect costs, presenteeism, sickness absenteeism.

\section{Introduction}

Rheumatic diseases are chronic and progressive diseases. They cause damage to the locomotor system, lead to disability and thus decrease the quality of life of the patient. Inflammatory rheumatic diseases are particularly dangerous to health. According to the data of the National Institute of Public Health - National Institute of Hygiene it is estimated that in Poland about 400,000 persons suffer from inflammatory joint diseases, and these are mostly persons of working age [1]. The most frequently occurring inflammatory rheumatic diseases include rheumatoid arthritis (RA) and spondyloarthropathies. Connective tissue disease, such as systemic lupus erythematosus, Sjögren's syndrome, systemic sclerosis or dermatomyositis, occur less often. The most common rheumatic disorder is osteoarthritis, which is not an inflammatory condition. Rheumatic disorders related to locomotor organs are common and concern $30-40 \%$ of the European population [2]

Precise data on the rheumatoid arthritis prevalence for Poland are not available. Most of the estimations are based on epidemiological data from other countries. Until now it has been stated that RA prevalence is $0.5-1 \%$ of the population [3]. However, the most recent publication by Cross et al. indicates lower prevalence. Global prevalence of RA (for people aged 5-100 years) is 0.24\% (95\% $\mathrm{Cl}: 0.23-0.25 \%)$. In the group of women this indicator is almost three times higher in comparison to the group of men and is $0.35 \%(0.34-0.37 \%)$. The prevalence in the group of men is $0.13 \%(0.12-0.13 \%)$. The prevalence of RA in Eastern Europe is $0.14 \%$ (0.08-0.22\%) for men and $0.38 \%(0.24-0.57 \%)$ for women. For Central Europe it is $0.15 \%(0.11-0.19 \%)$ for men and $0.41 \%(0.31-0.52 \%)$ for women, whereas in Western Europe it is $0.24 \%$ (0.21$0.28 \%)$ for men and $0.63 \%$ (0.55-0.75\%) for women [4].

Address for correspondence:

Anna Kłak, Department of Prevention of Environmental Hazards and Allergology, Medical University of Warsaw, Banacha 1 A,

02-097 Warsaw, Poland, e-mail: anna.klak@wum.edu.pl

Submitted: 5.08.2015, Accepted: 6.10.2015 
Based on the values for Central Europe there should be 19,000 to 33,000 males and 59,000 to 98,000 females in Poland suffering from rheumatoid arthritis at the age from 5 years and above. The average number of persons suffering from rheumatoid arthritis is 100,000 . For comparison, according to National Health Fund data for the years 2004-2012 there were from 135,000 to 157,000 patients in Poland per year treated for RA (M05, M06) [5]. A frequent consequence of the disease is the inability to function on the labour market. The most common problems of everyday life reported by patients suffering from rheumatic diseases include getting dressed, getting up, turning the tap on, opening the cap of the bottle, getting on the bus and not having a free seat, inability to use stairs and open heavy doors, and inability to stand for a long period of time. The problems with performing simple activities of everyday life have a significant impact on the loss of independence, hamper social relations and may even constitute a risk of poverty. Rheumatic diseases also contribute to multiple organ failures, which often lead to death [6].

Rheumatic diseases, inflammatory ones in particular, entail many different consequences in the area of health, psychology and society. It is also reflected in the losses incurred by the state and economy. The analyses of this issue are based mostly on the estimation of direct and indirect costs.

\section{Methods of calculating indirect economic costs and their limitations}

Indirect costs of the disease are related to the loss of productivity as a result of the disease, disability or premature death of the patient. Indirect cost characterizes the disease and not health technology, which, on the other hand, can contribute to the reduction of indirect costs of the disease [7].

Two main models of the assessment of indirect costs can be distinguished. The first model assumes that decreased productivity is the factor that generates an additional economic burden. It is therefore a parameter the influence of which is visible at the costs level. The second model, represented by the method of assessing the health status, assumes that decreased productivity is the factor associated mainly with decreased quality of life. Therefore the influence of this parameter is visible at the health outcomes level [8].

Two methods of assessing indirect costs can be distinguished within the first model: the human capital approach (HCA) and the friction cost approach (FCA). The human capital approach assumes that each loss of productivity that results from the disease of an individual patient is treated as a cost for the society. On the other hand, the friction cost approach assumes that the loss of productivity of the patient constitutes a burden for the society only to the extent that the society is unable to fill this gap. Therefore in the case of the human capital approach the person leaving work and receiving an indefinite pension generates indirect costs until the end of the working cycle, whereas in the friction cost approach this applies only until the person is replaced by another employee (which lasts for a few months on average).

The opponents of the human capital approach claim that its main limitations are as follows:

- the productivity loss as seen from the society level is overestimated, as the employees that leave the labour market because of the disease can be replaced in a shorter period of time than the achievement of post-working age,

- the periods of business cycle are not taken into account,

- the assumptions of the labour market that indicate the lack of unemployment and full productivity of the remaining employees are not fulfilled,

- the evaluation of productivity loss is potential (maximum), not actual [8].

On the other hand, the limitations of the friction cost approach include:

- the assumption that diseases and work absenteeism reduce the overall unemployment of the population; however, there are no data indicating this dependency in the long term,

- the assumption that an almost perfect market of employees ready to replace the lost employees exists,

- underestimation of the time dedicated to the search for a new employee that is evaluated in the friction cost approach, e.g. in the case of low unemployment, the companies may not search for a new employee,

- the use of the method is limited to work only; therefore it cannot be applied to analyse the productivity loss in the case of domestic activities [8].

In the second of the above-mentioned models - the assessment of health status - it is indicated that the evaluation of the quality of life should include the productivity loss of the patient. The method of assessing health status assumes that the indirect cost of productivity loss constitutes a burden only at the level of health outcomes. Therefore its economic estimate is not needed. In the human capital approach and friction cost approach the limited productivity is additionally estimated in monetary units [8].

\section{Indirect costs of rheumatic diseases}

In the category of indirect costs one of the key positions is related to premature exit from the labour market 
due to disease (pension, early retirement) and medica sick leave (absenteeism). Sometimes unemployment caused by the disease and informal absence from work, when an employee leaves work for a medical appointment, are also taken into account. The new approach in the studies dedicated to indirect costs also includes the costs related to presenteeism, which is ineffective presence at work while sick [7, 9]. Some of the above-mentioned phenomena can be described based on the data collected by public institutions with their statutory activity, e.g. the Social Insurance Institution (SII).

\section{Expenditures relating to incapacity for work - the Social Insurance Institution data}

The data published by the Social Insurance Institution indicate that in 2012 total expenditures relating to the incapacity to work from the national budget and paid out of the own resources of the employers amounted to 30.4 billion PLN, equivalent to $1.9 \%$ of GDP. Most of these resources (over 15 billion PLN) were dedicated to work incapacity pensions. The expenditures relating to sickness absenteeism amounted to over 12.2 billion PLN, social pensions to 1.8 billion PLN, rehabilitation benefits to 1.1 billion PLN and therapeutic rehabilitation to nearly 0.2 billion PLN [10].

The reports on the expenditures relating to the incapacity to work published by the SII present only the data relating to groups of diseases and not particular disease entities. Therefore the information presented below concerns the whole group of diseases of the musculoskeletal system and connective tissue (M00-M99), without differentiating inflammatory and non-inflammatory diseases.

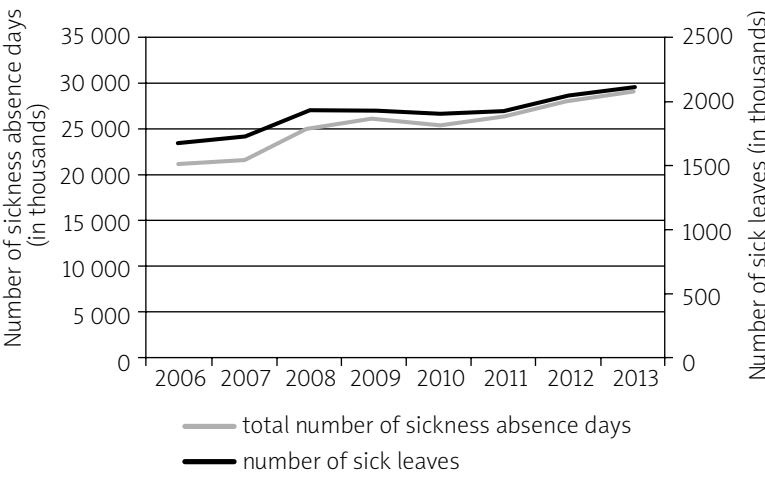

Fig. 1. Total number of absence days and sick leaves due to own sickness among persons insured by the Social Insurance Institution (SII) (diseases of the musculoskeletal system and connective tissue) in the years 2006-2013. Source: Own work based on SII data.
The expenditures relating to the incapacity to work benefits (among others, pensions and sickness benefits) received in 2012 due to diseases of the musculoskeletal system and connective tissue amounted to 3.9 billion PLN, which accounted for $12.9 \%$ of total expenditures for that year. As much as $60.6 \%$ of the expenditures in this group of diseases are the benefits granted to men [10].

The expenditures relating to work incapacity pensions due to diseases of the musculoskeletal system and connective tissue in 2012 amounted to nearly 2 billion PLN, out of which $65.2 \%$ were allocated for pensions grated to men. Locomotor system diseases represented the third, in respect of total costs (13\%), reason for work incapacity. Cardiovascular diseases occupied first place (24.4\%) and mental and behavioural disorders the second (19.4\%) [10].

The expenditures relating to sickness absenteeism financed by the Social Insurance Fund (FUS) and employers fund in 2012 due to diseases of the musculoskeletal system and connective tissue amounted to 1.6 billion PLN, out of which $57.9 \%$ was related to absenteeism among men.

\section{Sickness absence (absenteeism)}

Sickness absence is most frequently mentioned in the context of indirect costs of diseases. It results from the fact that the data on this issue are available in the form of different types of data collection. They refer only to part of the population - mainly persons of working age $(98 \%$ of the sickness absence due to own sickness registered by the Social Insurance Institution in 2012 was generated by persons aged 20-64 years) who are employed or self-employed.

In 2013 as many as 2.1 million sick leaves due to diseases of the musculoskeletal system and connective tissue (M00-M99) were registered by the Social Insurance Institution, which corresponded to over 29.2 million sickness absence days. It is over 8 million days more than in 2006 (Fig. 1). In 2013, diseases of the musculoskeletal system and connective tissue were the reason for $13.7 \%$ of total sickness absence in Poland and $12.2 \%$ of sick leaves, which constituted the fourth most frequent reason for sickness absence [11].

Table I presents the number of sickness absence days due to own sickness and the number of medical certificates issued for selected disease entities in the years 2012-2013. The data of the Social Insurance Institution include only the main categories according to ICD10 and do not include the sub-categories (e.g. L40.5).

As many as 35,000 sick leaves due to own sickness were issued in 2013 because of rheumatoid arthritis (M05, M06) for the total amount of 535,400 days. For 
Table I. The number of sickness absence days due to own sickness and the number of medical certificates issued in the years 2012-2013 due to selected disease entities

\begin{tabular}{|c|c|c|c|c|c|}
\hline \multirow[t]{2}{*}{ ICD10 code } & \multirow[t]{2}{*}{ Disease entity } & \multicolumn{2}{|c|}{2012} & \multicolumn{2}{|c|}{2013} \\
\hline & & $\begin{array}{c}\text { Number of } \\
\text { sickness } \\
\text { absence days }\end{array}$ & $\begin{array}{l}\text { Number } \\
\text { of medical } \\
\text { certificates }\end{array}$ & $\begin{array}{l}\text { Number of } \\
\text { sickness } \\
\text { absence days }\end{array}$ & $\begin{array}{l}\text { Number } \\
\text { of medical } \\
\text { certificates }\end{array}$ \\
\hline M05 & Seropositive rheumatoid arthritis & 356257 & 20955 & 356281 & 21123 \\
\hline M06 & Other rheumatoid arthritis & 204073 & 14294 & 196158 & 13733 \\
\hline M08 & Juvenile arthritis & 6062 & 465 & 6259 & 535 \\
\hline M10 & Gout & 279892 & 30346 & 280130 & 30602 \\
\hline M32 & Systemic lupus erythematosus & 56767 & 3518 & 56164 & 3567 \\
\hline M45 & Ankylosing spondylitis & 104925 & 6927 & 107982 & 7137 \\
\hline
\end{tabular}

Source: Own work based on Social Insurance Institution data.

comparison, ankylosing spondylitis (M45) was the cause of 108,000 days of sickness absence and systemic lupus erythematosus (M32) of 56,200 days. As most of the patients suffering from juvenile arthritis (M08) have not reached the age of 18 , the data on sickness absence due to own sickness are not reliable in this case. The days of sickness absence due to childcare should be added to the values presented above (particularly in the case of juvenile arthritis) or the care for a family member of the insured, which has not been taken into account. The data are available without the division into disease entities or diagnosis groups, which makes it impossible to use them for the presentation of costs relating to the selected diseases of the musculoskeletal system and connective tissue.

The information on the sickness absence days is highly important in the context of indirect costs of the disease, but it does not demonstrate the influence of a given disease entity on the economy and gross domestic product (GDP). In the case of persons insured by the Social Insurance Institution, according to Article 92 of the Labour Code, the costs of sickness absence during the first 33 days of incapacity to work in a calendar year are borne by the employer (14 days in the case of employees who have reached 50 years of age) [12]. Only after this period is sickness allowance paid by the SII. The sickness allowance is $70-100 \%$ of the salary depending on additional circumstances.

Converting the sickness absence into monetary equivalent bears a significant limitation resulting from the underlying assumptions. However, it is commonly used in the analysis of indirect costs. In the case of RA the total number of sickness absence days amounted to 535,400, which corresponds to 1,513.5 years (assuming that there are 365 days in a year ${ }^{1}$ ). According to the methods presented in an Ernst \& Young (EY) report on the calculation of indirect costs [13], gross domestic product has been adopted as the measure of productivity which was calculated per one employee. The indicator amounted in 2013 to 115,421 PLN [13, 14].

Taking into account that the present article refers to the information from the Social Insurance Institution for 2012 and 2013, the data of the Central Statistical Office of Poland relating to GDP in 2013 as well as the data relating to the persons employed in the national economy at the end of 2012 were used for calculations. The data relating to the persons employed in the national economy at the end of 2013 were not available yet. Based on the assumptions made, the total productivity loss as a result of sickness absence due to RA amounted to 174.7 million PLN. This value should be reduced using a correction coefficient of $0.65^{2}$, which corresponds to the marginal relation with respect to average work productivity adopted by the European Commission [7, 13]. The definitive indirect cost of sickness absence due to RA in 2013 was estimated at 113.5 million PLN. For comparison, the indirect cost of sickness absence due to systemic lupus erythematosus (11.7 million PLN) and ankylosing spondylitis (21.6 million PLN) was calculated. It should be noted that inflammatory rheumatic disorders,

\footnotetext{
${ }^{1}$ It has been proposed in the report by EY to use working years, assuming that each calendar year includes 250 working days. It should be however noted that Social Insurance Institution data on sickness absence do not take into account only working days, but calendar days. According to the Social Insurance Institution the number of sickness absence days is determined based on a medical certificate as the difference between the position "incapacity to work until" and "incapacity to work from". Therefore a safer solution is to divide the total number of sickness absence days by 365 in order to obtain the value measured in years. However, when applying this method, the obtained value may be underestimated.

${ }^{2}$ The coefficient refers to marginal relations with respect to average work productivity adopted by the European Commission. In this case the unit of measure will adopt the following formula: unit of productivity $=$ GDP per employee * 0.65
} 


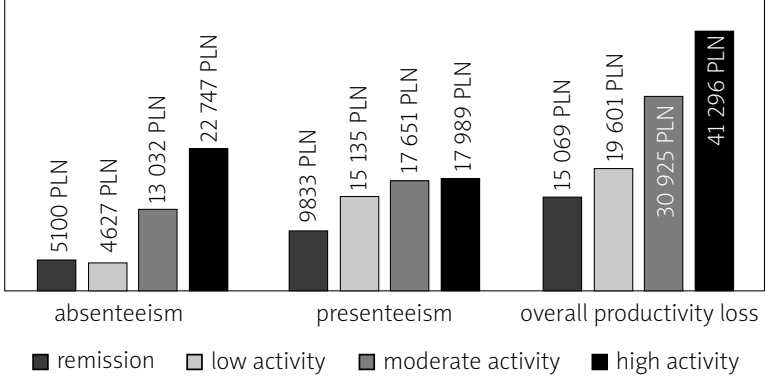

Fig. 2. Indirect costs of RA calculated per person with respect to disease activity (unit cost based on GDP value/employee).

Source: Own work based on [7].

RA in particular, lead rapidly to disability and withdrawa from the labour market. The presented costs of sickness absence include only the persons who remain in the labour market and are currently employed.

\section{Presenteeism - ineffective presence at work}

Presenteeism is ineffective presence at work due to sickness or coming to work while sick. The situation occurs when an employee comes to work but due to the disease or ill health is not fully productive [9]. The use of presenteeism to estimate the indirect costs of the disease is controversial as there are no objective methods for its measurement [7]. On a standard basis the studies are based on questionnaire tools. The respondents are asked questions about work and the influence of the disease on work [9].

At present many tools that differ significantly can be used to measure presenteeism. One of them is the questionnaire Work Productivity and Activity Impairment (WPAI) used by the Central and Eastern European Society of Technology Assessment in Health Care (CEESTAHC) in the Polish study Move to Work - Effective at work (M2W), which was the continuation of the project Fit for Work (F4W). The results of the studies were presented in the report "Indirect costs of immunemediated inflammatory diseases in Poland", developed within the project "Constructive. Healthy - Active - Constructive" [7, 15]. The costs of ineffective presence at work due to rheumatoid arthritis were determined within the study. The estimation with the human capital approach was used. In the analysed group of 814 persons suffering from RA (women aged 18-60 years and men aged 18-65 years) 57\% were professionally active and $42 \%$ of the persons were working in the week preceding the study. The indirect costs relating to presenteeism were estimated on the basis of both the GDP value and the average gross hourly rate. Us- ing the first method, the costs amounted to nearly 16,500 PLN per person yearly, and with the second method to 10,900 PLN. It should be noted that in both cases the indirect costs due to presenteeism were higher than the costs relating to sickness absence (absenteeism), which were 12,900 PLN and 8,600 PLN, respectively.

The influence of the disease activity on consequential indirect costs was also evaluated within the Move to Work study (Fig. 2). Annual costs of presenteeism, calculated per person (based on GDP value) in the case of RA remission were 9,800 PLN. Moderate or high disease activity increases the costs of ineffective presence at work up to 17,600-18,000 PLN. Similarly calculated costs of sickness absence for a person in remission of the disease amounted to 5,100 PLN and in the case of high activity of the disease to 22,700 PLN [7].

Based on the data relating to the epidemiology of individual disease entities, the authors of the report presented the estimate of indirect costs, including presenteeism, for the whole country. In the case of RA the cost of ineffective presence at work, calculated based on GDP value, amounted to 860 million PLN per year. In the case of using the gross hourly rate for calculation, it amounted to 570 million PLN per year. For comparison, the cost of sickness absence was estimated at 680 million PLN using the first method and at 450 million PLN using the second method [7]. The costs of sickness absence in the case of RA calculated based on the results of the Move to Work study differ significantly from the values estimated based on Social Insurance Institution data. The discrepancy of the results is due to the fact that in the first case the estimates are based on the declarations of patients relating to the sickness absence and in the second on the data from sick leave forms. Both methods are legitimate, but it should be noted that each of them entails a certain risk of error.

\section{Indirect costs of rheumatoid arthritis in Poland}

The data presented above concern the estimation of sickness absence and presenteeism costs in RA. Below an attempt at overall assessment of indirect costs is presented. The authors of the report "Indirect costs in health technology assessment" estimated the number of patients suffering from RA in Poland at 220,000 persons (year 2014). Within this group 121,000 persons are of working age, including 52,000 who are working. These values were obtained assuming that the coefficient of persons who are working in the population of RA patients of working age is $43 \%$ (the estimations were based on the previously mentioned Move to Work cross-cutting study). The authors of the report estimated that, in view of public finance, the assessment of 
disease costs the annual RA expenditure (including social benefits, health services and drugs) is 50\% higher than the expenditure of only the public payer (National Health Fund) [8].

It was estimated that the costs calculated using the second approach - human capital - amount to 2.8 billion PLN and exceed the costs calculated with the friction cost approach more than twofold (1.2 billion PLN). The difference results from the method of estimating the costs relating to productivity loss due to permanent incapacity for work (long-term absenteeism) (Table II) [8].

The current analysis did not include the increase in health costs in the household budgets of RA patients as well as the influence of the disease on the economic status of the patient and his or her household. According to the study by Grygielska, carried out in the years 2009-2010, that included 1,000 RA patients in Poland, the development of rheumatoid arthritis influences the economic condition of the patients' household. It was found that the incomes are limited, and compared to the average the monthly health expenditure per person is almost twice as high. In an average household the monthly health expenditure per person is $47.90 \mathrm{PLN}$, whereas in the household of an RA patient it is almost twice as much, i.e. 93.37 PLN. As many as 49\% of RA patients' households experience financial difficulties, with $20 \%$ of households reporting financial difficulties in the Central Statistical Office studies. The assistance of third parties considerably influences the costs of RA [16].

\section{Costs of rheumatoid arthritis worldwide}

Indirect costs generated by RA patients have been analysed by researchers all over the world. The outcomes of the analysis carried out in Germany by Hus cher et al. [17] indicated that in the group of RA patients of working age (18-64 years) the indirect costs of sick leaves and permanent incapacity for work constitute a significant part of the yearly cost of the patient from the social perspective. The costs of sick leaves (per capita) over 10 years decreased from 1,707 EUR in 2002 to 1,525 EUR in 2011. Permanent incapacity for work constitutes the main component of indirect costs. Calculated using the FCA method, the costs relating to permanent incapacity for work decreased from 1,680 EUR in 2002 to 1,552 EUR in 2011. Using the HCA method these costs amounted to 8,902 EUR and 8,229 EUR respectively. Total indirect costs decreased within the analysed period. Depending on the method used, the difference amounted to 310 EUR (FCA) and 855 EUR (HCA) [17]. The outcomes of the analysis carried out in Austria by Radner et al. in a group of 356 RA patients showed a statistically
Table II. The costs of RA from social perspective

\begin{tabular}{|lcc|}
\hline Category & $\begin{array}{c}\text { Friction cost } \\
\text { approach }\end{array}$ & $\begin{array}{c}\text { Human } \\
\text { capital } \\
\text { approach }\end{array}$ \\
\hline Direct costs of RA & \multicolumn{2}{c|}{$395.8 \mathrm{~m} \mathrm{PLN}$} \\
\hline Short-term absenteeism & $577 \mathrm{~m} \mathrm{PLN}$ & $577 \mathrm{~m} \mathrm{PLN}$ \\
\hline Long-term absenteeism & $9 \mathrm{~m} \mathrm{PLN}$ & $1,554 \mathrm{~m} \mathrm{PLN}$ \\
\hline Informal care & $251 \mathrm{~m} \mathrm{PLN}$ & $251 \mathrm{~m} \mathrm{PLN}$ \\
\hline Total & $1,233 \mathrm{~m} \mathrm{PLN}$ & $2,778 \mathrm{~m} \mathrm{PLN}$ \\
\hline
\end{tabular}

Source: Own work based on [8].

significant relation between the activity of the disease and indirect costs: the increase in the disease activity entails the increase in the costs relating to incapacity for work $(p<0.01)$. A similar relation was observed for annual cost of sick leaves. In the group of patients with low disease activity it amounted to 1,874.2 EUR, whereas in the group of patients with high disease activity it amounted to 3,291.9 EUR [18].

The results of the study carried out in Norway by Kvamme's team in a group of 1152 RA patients demonstrated that during the two-year observation period the indirect cost in the group treated with classic disease-modifying antirheumatic drugs (DMARD) measured with the HCA method amounted to 66,975 EUR, whereas measured with the FCA method it amounted to 20,420 EUR. A two-year period of biological therapy measured with the HCA method generated the cost of 122,233 EUR, whereas measured with the FCA method it was 57,910 EUR. The authors calculated the cost of productivity loss within the group. In the group of patients treated with classic disease-modifying antirheumatic drugs it amounted to 57,564 EUR (HCA method) and 13,881 EUR (FCA method), whereas in the group of patients undergoing biological therapy it amounted to 82,754 EUR (HCA) and 18,807 EUR (FCA) [19].

Table III complements the articles described above and shows the remainder of the results of analyses of a number of indirect costs relating to the treatment of RA, which have been published in the last 3 years [17-19].

The results of the study carried out in Sweden in the years 1996-1998 by Hallert et al. [20] in a group of 320 RA patients demonstrated that in the first year of the study indirect costs were almost three times higher in the group of patients with DAS $-28^{3} \geq 3.2$ than in the group of patients with DAS- $28<3.2$. Indirect costs were calculated using the HCA method. An increase in indirect costs in the group of patients aged under 65 was demonstrated, both among the patients with DAS-28 $\geq 3.2$ and those with DAS-28 below 3.2 Table IV presents indirect costs obtained within this study.

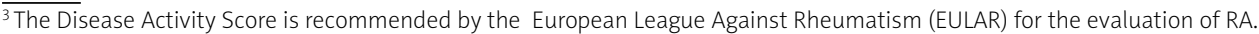


Table III. Indirect costs of RA treatment in the world calculated with friction cost approach and human capital approach

\begin{tabular}{|c|c|c|c|c|c|c|}
\hline $\begin{array}{l}\text { Author, year of } \\
\text { publication }\end{array}$ & $\begin{array}{l}\text { Country of } \\
\text { the study }\end{array}$ & $\begin{array}{l}\text { Year } \\
\text { of the } \\
\text { study }\end{array}$ & $\begin{array}{l}\text { Age of the } \\
\text { respondents }\end{array}$ & $\begin{array}{l}\text { Number of } \\
\text { the study } \\
\text { group }\end{array}$ & Total cost HCA & Total cost FCA \\
\hline $\begin{array}{l}\text { Huscher et al. } \\
2015 \text { [17] }\end{array}$ & Germany & $\begin{array}{c}2002- \\
2011\end{array}$ & $18-65+$ & $3,400^{*}$ & $\begin{array}{l}\text { Increase from } 15,523 \\
\text { EUR in } 2002 \text { to } 17,960 \\
\text { EUR in } 2011^{\star \star}\end{array}$ & $\begin{array}{c}\text { Increase from } 8,302 \text { EUR } \\
\text { in } 2002 \text { to } 11,283 \text { EUR } \\
\text { in } 2011^{\star *}\end{array}$ \\
\hline $\begin{array}{l}\text { Radner et al. } \\
2014 \text { [18] }\end{array}$ & Austria & $\begin{array}{l}2008- \\
2009\end{array}$ & $\begin{array}{l}\text { Average: } \\
59.9 \text { years }\end{array}$ & 356 & $\begin{array}{c}\text { 5,772.8 EUR^ } \\
7,186.6 \text { EUR } R^{\wedge} \\
10,525.7 E^{\wedge} R^{\wedge} \wedge\end{array}$ & $\begin{array}{c}\text { 917.5 EUR^ } \\
1,142.1 \mathrm{EUR}^{\wedge} \wedge \\
1,672.5 \mathrm{EUR}^{\wedge \wedge}\end{array}$ \\
\hline $\begin{array}{l}\text { Kvamme et al. } \\
2012 \text { [19] }\end{array}$ & Norway & $\begin{array}{l}2010- \\
2011^{\#}\end{array}$ & $\begin{array}{l}\text { Average: } \\
57 \text { years }\end{array}$ & 1,152 & $\begin{array}{l}14,122 \text { EUR } \\
20,436 \text { EUR }^{b}\end{array}$ & $\begin{array}{l}325^{a} \\
195^{b}\end{array}$ \\
\hline
\end{tabular}

FCA - friction cost approach; HCA - human capital approach

${ }^{*}$ per year, ${ }^{* *}$ in the age group of 18-64 years, $\wedge$ REM - remission, $\wedge \wedge$ LDA - low disease activity, $\wedge \wedge \wedge H D A$ - high disease activity/MDA moderate disease activity, ${ }^{a}$ patients treated with classic disease-modifying antirheumatic drugs, ${ }^{b}$ patients treated with biological therapy, \#12-24 months divided by 2

Source: Own work based on [17-19].

Table IV. Indirect costs per patient (in EUR) calculated within 4 days in 3-month periods of observation

\begin{tabular}{|c|c|c|c|c|}
\hline $\begin{array}{l}\text { Year of } \\
\text { the study }\end{array}$ & & $\begin{array}{l}\text { DAS- } 28<3.2, \\
\text { average cost }\end{array}$ & $\begin{array}{c}\text { DAS- } 28>3.2 \\
\text { average cost }\end{array}$ & $p$ \\
\hline \multirow[t]{2}{*}{1} & Indirect costs for the total number of patients & $3,918 €$ & $11,200 €$ & $<0.001$ \\
\hline & Indirect costs in the group of persons aged $<65$ & $5,500 €$ & $17,938 €$ & $<0.001$ \\
\hline \multirow[t]{2}{*}{2} & Indirect costs for the total number of patients & $5,732 €$ & $10,066 €$ & 0.014 \\
\hline & Indirect costs in the group of persons aged $<65$ & $8,188 €$ & $15,831 €$ & 0.002 \\
\hline \multirow[t]{2}{*}{3} & Indirect costs for the total number of patients & $7,123 €$ & $9,913 €$ & 0.215 \\
\hline & Indirect costs in the group of persons aged $<65$ & $10,006 €$ & $15,100 €$ & 0.098 \\
\hline \multirow[t]{2}{*}{4} & Indirect costs for the total number of patients & $5,825 €$ & $11,197 €$ & 0.058 \\
\hline & Indirect costs in the group of persons aged $<65$ & $7,456 €$ & $17,344 €$ & 0.008 \\
\hline
\end{tabular}

Source: Own work based on [20].

The cost of sick leaves and early retirement pensions in the first year of observation was three times higher in the group of patients with DAS-28 > 3.2 than in the group of patients with DAS- $28<3.2$ (respectively: 9,055 EUR vs. 3,202 EUR and 2,145 EUR vs. 716 EUR). In the second year of observation the costs amounted to respectively 5,490 EUR vs. 3,815 EUR (sick leaves) and
4,634 EUR vs. 1,835 EUR (early retirement pensions). In the third year of observation the costs were as follows: 4,081 EUR vs. 2,833 EUR (sick leaves) and 9,913 EUR vs. 7,123 EUR (early retirement pensions), whereas in the fourth year they were 1,368 EUR vs. 2,755 EUR (sick leaves) and 9,829 EUR vs. 3,069 EUR (early retirement pensions) [20]. 


\section{Summary}

The presented costs relating to diseases of the musculoskeletal system and connective tissue, rheumatoid arthritis in particular, are not complete. An attempt to estimate the indirect costs relating to the death of the patients was not made. This was due to the fact, among others, that the data on mortality due to rheumatic diseases are seriously underestimated, and hence not very reliable. The costs relating to sickness absence due to the care for disabled persons were not taken into account.

Regardless of the limitations of the presented data, some issues need to be noted. Firstly, an increase in the number of sick leaves has been observed for some years (as well as the total number of sickness absence days) due to diseases and disorders of the locomotor system, including rheumatoid arthritis. This demonstrates a growing problem that will more significantly influence the labour market in Poland. Secondly, in the case of the diseases of the musculoskeletal system and connective tissue, indirect costs substantially exceed direct costs incurred by the payer and allocated to benefits due to rheumatic disorders. Rapid remission of the disease results not only in considerable improvement of the patient's quality of life, but also in a significant reduction of indirect costs. The chance of remission is closely linked to the time between the first symptoms, diagnosis and efficient treatment. This is another argument in favour of the introduction of solutions that would facilitate the access of patients to early diagnosis of inflammatory joint diseases, particularly in the case of rheumatoid arthritis. The increase in these costs, together with the increase in disease activity, has been illustrated by the case of rheumatoid arthritis.

The authors declare no conflict of interest.

\section{References}

1. Narodowy Instytut Zdrowia Publicznego - Państwowy Zakład Higieny. Tabele wynikowe Badania Chorobowości Szpitalnej Ogólnej. http://www.statystyka.medstat.waw.pl/wyniki/TabelaEurostat2012szac.htm [Accessed: 15.04.2014].

2. Oświadczenie Parlamentu Europejskiego w sprawie chorób reumatycznych, 2009/C 285 E/11.

3. Scott DL, Wolfe F, Huizinga TW. Rheumatoid arthritis. Lancet 2010; 376: 1094-1108.

4. Cross M, Smith E, Hoy D, et al. The global burden of rheumatoid arthritis: estimates from the Global Burden of Disease 2010 study. Ann Rheum Dis 2014; 73: 1323-1330.

5. Śliwczyński A. Epidemiologia zapalnych chorób stawów w Polsce. 32. Konferencja Ordynatorów i Kierowników Poradni Reumatologicznych (Warszawa 23-24 maja 2013). Materiały zjazdowe.
6. Listing J, Kekow J, Manger B, et al. Mortality in rheumatoid arthritis: the impact of disease activity, treatment with glucocorticoids, TNF $\alpha$ inhibitors and rituximab. Ann Rheum Dis 2015; 74: 415-421.

7. Bebrysz M, Fedyna M, Rutkowski J i wsp. Przewlekłe choroby zapalne mediowane immunologicznie - ocena kosztów pośrednich w Polsce. Central and Eastern European Society of Technology Assessment in Health, Kraków 2014.

8. Władysiuk M, Szmurło D, Kostrzewska K, et al. Koszty pośrednie w ocenie technologii medycznych. Metodyka, badanie pilotażowe i rekomendacje dla Polski. HTA Consulting, Warszawa 2014.

9. Raciborski F, Władysiuk M, Bebrysz $M$, et al. Utrata produktywności w następstwie chorób reumatycznych - absencja i prezenteizm. Reumatologia 2013; 51: 355-362.

10. Karczewicz E, Kania A. Wydatki na świadczenia z ubezpieczeń społecznych związane z niezdolnością do pracy w 2012 r. Zakład Ubezpieczeń Społecznych, Warszawa 2014.

11. Karczewicz E, Sikora A. Absencja chorobowa w 2013 roku. Zakład Ubezpieczeń Społecznych, Warszawa 2014.

12. Ustawa z dnia 26.06. 1974 roku Kodeks pracy. Dz. U. nr 24, poz. 141.

13. Metodyka pomiaru kosztów pośrednich w polskim systemie ochrony zdrowia. Raport opracowany przez EY na zlecenie Związku Pracodawców Innowacyjnych Firm Farmaceutycznych INFARMA. Warszawa 2013.

14. Główny Urząd Statystyczny. Polska - wskaźniki makroekonomiczne (PKD 2007). http://stat.gov.pl/wskazniki-makroekonomiczne/ [Accessed: 14.06.2014.].

15. Projekt „Konstruktywni. Zdrowi - Aktywni - Konstruktywni” http://www.konstruktywni.org.pl/pl/wydajni-w-pracy/47 [Accessed: 27.04.2015].

16. Grygielska J. The impact of rheumatoid arthritis on the economic situation of Polish households. Reumatologia 2013; 51: 348-354.

17. Huscher D, Mittendorf T, Hinüber U, et al. Evolution of cost structures in rheumatoid arthritis over the past decade. Ann Rheum Dis 2015; 74: 738-745.

18. Radner H, Smolen JS, Aletaha D. Remission in rheumatoid arthritis: benefit over low disease activity in patient-reported outcomes and costs. Arthritis Res Ther 2014; 16: R56.

19. Kvamme MK, Lie E, Kvien TK, Kristiansen IS. Two-year direct and indirect costs for patients with inflammatory rheumatic joint diseases: data from real-life follow-up of patients in the NOR-DMARD registry. Rheumatology 2012; 51: 1618-1627.

20. Hallert E, Husberg M, Skogh T. 28-joint count disease activity score at 3 months after diagnosis of early rheumatoid arthritis is strongly associated with direct and indirect costs over the following 4 years: the Swedish TIRA Project. Rheumatology 2011; 50: 1259-1267. 